\title{
Cutaneous Mature B-Cell Neoplasm
}

National Cancer Institute

\section{Source}

National Cancer Institute. Cutaneous Mature B-Cell Neoplasm. NCI Thesaurus. Code C45249.

A B-cell neoplasm that arises from the skin. 